\title{
Municipal budgets under conditions of economic crises in Russia
}

\author{
Timergaziz Gabidullovich Sadykov, Razifa Raisovna Stepanova \\ Ufa State Petroleum Technological University, Branch of the University in the City of Oktyabrsky, Russian Federation
}

\begin{abstract}
The modern stage of Russia's integration into global community has led to its great dependence on global economy. Russia has become a part of global economy. As all the countries are involved in the world economic functions the size and the consequences of global financial and economic crisis is becoming more and more meaningful for Russian economics as well. The objective of the present paper is to study the general impact of the crisis on Russian budget system and the special impact on the municipal level. The authors consider important to analyse the papers of various economists.
\end{abstract}

\section{Introduction}

The latest consequences of financial and economic crises make a rather significant impact on Russian financial system due to the following drop of prices of energy and raw materials which are the primary source of the federal budget revenue. Not by coincidence the crisis developments in economy have influenced primarily fuel and energy as well as raw materials sectors. Therefore, the effects of the economic crisis have started to manifest themselves in the regions where these industries are located and function.

Moreover, the negative consequences of the crisis are witnessed with regards to the decline in profits and real income of the population being the aftereffects of decline in employment and high inflation [1]. According to the international experience and national practice all the impacts mentioned above lead to the rapid inflationary development. Modern financial and economic crisis combined with all-Russian systemic crisis makes major impact on the operation of the budget systems of Russia, its regions and municipal entities, dictating the need for the primary budget expenditures minimization. It is one of the objectives of the anti-recessionary measures of the Federal Centre, regions, Government of the Russian Federation together with the recession-busting deals and initiatives of the territorial entities of the Russian Federation.

The role of the theory and practice of anti-crisis management in municipal entities increases under the conditions of regional economic restructuring. Overcoming the crisis in municipalilies is a constituent part of regional economic policy. Crises are complex and contradictory phenomena. They involve utmost aggravation of contradictions in economic and social systems with further threat to their stability and viability. The reasons evoking the crisis manifestaion of the systems' socio-economic development are devided into objective, involved with the cyclic developmental character, and subjective, disclosing the mistakes and a lack of competence in management. The bases of crises can be represented by natural and technology-related processes. There is always the probability of a crisis and it should be foreseen and anticipated.

Within this framework anti-crisis management can be presented in the system of measures for diagnosing, anticipating, counterpoising and overcoming crisis developments and their reasons at all economic levels including the level of municipal entities.

\section{Ways to resolve crisis}

The conducted research shows that crises pose greater problems for regional budgets especially local ones rather than for federal budget.

At the current stage in Russia's development the role of local self-governments is multiplied [2]. Consequently, local budget is the basis of the financial system of municipal entities and, subsequently, financial instability under the conditions of crisis poses additional challenges with regards to creating economic basis and their budget establishment.

In the meantime, the complexity of municipal budget establishment and management is dramatized by a set of following factors:

- economic basis development disparity;

- social infrastructures difference;

- unnecessarily centralized planning and control;

- inability to consider the challenges of specific municipal entities.

\footnotetext{
* Corresponding author: riuof@mail.ru
} 
All of these things influence economic efficiency, development and the state of municipal budget. Experience has shown that lack of financial backing from federal and regional budgets makes municipal budget insufficient for addressing local issues.

Practically it means that local budgets are mainly formed at the expense of inter-budget transfers, grants and subsidies. Therefore, the paramount objective of local councils is to develop their own income basis and to pay attention to the growth of taxable capacity and improvement of local tax collection.

The local governments revenue is the major resource for the full exploitation of expenditure powers.

Not all municipal governments experience crisis similarly. The situation at hand requires the adoption of fast-track measures which must be primarily aimed to optimize spendings, save budget and establish a financial reserve $[3,4]$. It accounts stable functioning of the priority guidelines which are of social importance for the municipal government.

Financial sustainability of a municipal government can be achieved by continuous implementation of the anti-crisis measures directed at finding solutions to the following essential tasks:

- to improve budgets revenue base;

- to go into the constant mode of budget savings.

The present-day changes in politics and economics, in legal and budgetary relations between the levels and branches of government require a new, efficient and stable mechanism of controlling the municipal entities budgets especially during the crisis [5].

Anti-crisis management measures and specialists in this sphere are rather helpful under the conditions of crisis. Anti-crisis management in municipal entities is emergency management. Such organizations work on the specially developed programs focused on the conditions peculiar for each municipal entity. Each program includes the crisis projected growth and the possible ways of eliminating the critical situation and its consequences.

The program is based on the practical experience, crisis prevention and is directed at solving the exisiting tasks via anti-crisis management measures.

Their major objective is to find the method of encouraging the local government to develop and apply modern mechanisms of cost optimization and revenue increase [6].

In a loose sense, anti-crisis management in municipal entities is application of procedures with regard to a certain territory with the aim to avoid crisis and mitigate its adverse effects.

It seems clear that anti-crisis management is directed at eliminating crisis by means of tight and rapid measures with an emphasis on:

1. The framework and mechanism of budgetary and financial policy of a given municipality;

2. Inter-budget relations;

3. Relationship with the federal fund of financial backing;

4. Financial assistance;

5. Tax adjusting and tax revenue;

6 . Budgetary loans and subventions;
7. Budget gap.

The major objective in a time of fragile financial and economic situation is to set the priorities of a municipal budgetary policy, optimize financial control. Local governments must not only cut budget spending but also develop and propose new optimization technique of spending limited municipal funds [8,9].

Local governments gain particular importance under the conditions of crisis as they are capable of rendering prompt assistance to those people who wish to set up new businesses within their territory. Local governments' participation in realizing their territories potential create favourable conditions for the country to surmount the crisis [7].

Despite the problems occuring in municipal economics during the crisis, even more urgent are the tasks of qualified socio-economic development of municipal entities.

The problem of enriching the budgets, especially the local ones is becoming even more acute under the conditions of crisis. Revenue contraction of local budgets make them more dependent on inter-budget transfers from the budgets of other levels (with account of subventions). Consequently, the issue of necessity to grant a targeted aid to local budgets is one of the principal sources of income supplement.

Financial instability at a municipal level under the conditions of crisis poses additional challenges in securing the economic base. This problem can be solved by means of regional socio-economic development programs. It is the regional level which the actual resource status of socioeconomic potential of all municipal entities should be focused on under the conditions of crisis. As well, the regional level should provide the ground for identifying general issues, setting goals, working out the measures aimed at overcoming the economic crisis.

It should be noted that not all anti-recessionary measures taken at federal level, namely by regions and municipal entities, succeed.

Nowadays, the country (regions, cities, villages) require the market system able to manufacture the product competitive in the global market primarily for mass domestic consumption and providing solid labor market.

One of the main focuses under the conditions of crisis is promoting small-business development. Any type of small-business is closely linked to the territory on which it is set both from financial and legislative standpoint. Small businesses in particular will lead to the reduction of unemployment on the one hand, and to the local budget revenues increase on the other hand.

Crisis has revealed the negative aspects of inter-budget relations in the country.

The necessity to reconsider the mentioned issue seems to be rather obvious. An obstacle for municipal entities under the conditions of crisis is the constraint system concerning the scope of financial aid. Nowadays, the documented scope of aid is $50 \%$ of local revenues; however, in practice this indicator is much lower.

In addition to that, the present measures cannot bring significant changes to the state of the municipality 
economic basis while these measures are sufficient for partial solutions of the issues concerning social sphere and maintenance of infrastructure facilities. The measures insufficiency is characterized by calculating the costs required for maintaining the city territory and demonstrates that the existing size and growth rate of budget funds is several times smaller than it is required for instantaneous maintenance and site improvements.

There has been escalated an issue which can be solved by the introduction of a differential scale of assessments entering the local budget.

Despite the issues arising in municipal economics during the crisis the task of comprehensive socioeconomic development of municipal entities seems to be even more urgent. The self-governing authorities' effectiveness evaluation system being implemented nowadays does not lead to gaining beneficial effect with regards to overcoming crisis due to the lack of authentic municipal statistics required for analyzing actual economic status of municipal entities and projecting their socio-economic development.

The analysis of the works of many economists suggests that financial and economic crisis will continue during the following 3 to 5 years. Therefore, it is necessary to provide natural transformation including the above mentioned measures due to the fact that the crisis of municipal entities has become systematic and its management requires adopting systemic measures.

\section{Conclusion}

The methods of financial management are applied with the purpose to manage and plan the budgets of municipal entities, anticipate and efficiently perform official powers. The most appropriate methods under the conditions of crisis are as follows:

- the method of analysis and correction;

- the method of performance benchmarking.

According to our reckoning the situation concerning insufficient provision of local budget with financial assets can be improved by the present regulatory framework betterment and the introduction of alterations into industry-specific regulatory documents of the Federal Tax Service of Russia, the Federal Migration Service of Russia, the Federal Bailiffs Service of Russia, the Federal Real Estate Cadastre Agency of the Russian Federation, The Ministry of Internal Affairs of The Russian Federation, the Federal State Statistics Service of the Russian Federation rather than at the expense of upper budget levels [10, 11].

Thus, the whole legal and regulatory framework of the Russian Federation must be directed to the replenishment of budgets at all levels. Thereupon, it is necessary to create a new system of cooperation between th services, organize a new type of interaction between business and authority [12, 13]. It the onle way to provide money to the budgets and lay the groundwork for strong post-crisis economic growth.

\section{References}

1. N.H. Korsunova, The economic crisis in Russia and the state of the budget system. www.scienceforum.ru (2016)

2. A.G. Aganbegyan, Ekonomicheskaya politika, 12 (4), 8-29 (2017) DOI: 10.18288/1994-5124-2017-401

3. K.T. Tyncherov, V.Sh. Mukhametshin, L.B. Khuzina, Method to control and correct telemtry well information in the basis of residue number system, Journal of fundamental and applied sciences, 9 (2S), 1370-1374 (2017) DOI: 10.4314/jfas.v9i2s.848

4. M.A.A. Martinez, Revista general de derecho administrative, 40, (2015)

5. T.V. Sumskaya, Local government: the evolution of fiscal policy (Novosibirsk: IEOIP-P, 2016)

6. C.S. Carol, Russian review, 76 (4), 607-622 (2017)

7. DOI: $10.1111 /$ russ. 12149

8. N.T Dao, O. Edenhofer, Journal of macroeconomics, 55, 253-273 (2018) DOI: 10.1016/j.jmacro.2017.10.007

9. T. Addison, M. Nino-Zarazua, J. Pirttila, Journal of international development, 30 (2), 161-172 (2018) DOI: $10.1002 /$ jid.3355

10. L. Forni, M. Pisani, Macroeconomic dynamics, 22 (2), 470-500 (2018) DOI: 10.1017/S1365100516000286

11. M.A. Mateo-Perez, M.A. Martinez-Roman, Y. Domenech-Lopez, Revista de cercetare si interventie sociala, 50, 96-110 (2015)

12. E.R. Toro, Revista gestion de las personas y tecnologia, 9 (25), 6-19 (2016)

13. V.A. Mau, Voprosy ekonomiki, 3, 5-29 (2018)

14. R.M. Shaidullina, A.F. Amirov, V.S. Muhametshin, K.T. Tyncherov, Designing Economic Socialization System in the Educational Process of Technological University, Europ. J. of Contemp. Edu., 6 (1), 149158 (2017) DOI: 10.13187/ejced.2017.1.149. 